\title{
Competitive Advantage and Clusters: What Can We Learn from Nine Turkish Clusters?*
}

\author{
Nigar Çağla Mutlucan** \\ Beykoz University
}

\begin{abstract}
Many researchers have studied the ability of clusters to promote innovation, regional economic development, and national prosperity; however, these studies had been mostly conducted at the cluster level, not at the firm level. This study attempts to bring the cluster discourse back to the firm by answering the following research question: how do firms create and defend competitive advantages through clusters? The theoretical model presumes positive relationships between several constructs and firm performance, namely, business ties, support ties, entrepreneurial orientation and strategic learning capability. Furthermore, these relationships are supposed to be enhanced by the moderating effect of the cluster construct. The Partial Least Squares path model analysis of data from 160 surveyed firms located in nine Turkish clusters revealed that only entrepreneurial orientation and support ties contributed significantly and positively to firm performance.
\end{abstract}

Keywords: cluster, competitive advantage, performance, entrepreneurial orientation, business ties, support ties. JEL Classification: L26, D85, L25, L14

\section{Rekabetçi Avantaj ve Kümelenmeler: Dokuz Türk Kümelenmesinden Ne Öğrenebiliriz?}

\section{Özet}

Birçok araştırmacı kümelenmelerin inovasyona, bölgesel ekonomik gelişmeye ve milli refaha katkı yapma yetisini araştırmış, ancak bu çalışmalar çoğunlukla firma seviyesinde değil, kümelenme seviyesinde yürütülmüştür. Bu nedenle, bu çalışma firmaların kümelenmeler vasıtasıyla nasıl rekabetçi avantaj yarattıkları ve bunu nasıl savundukları sorusuna cevap aramış ve kümelenme ile ilgili söylemi tekrar firma seviyesine getirmeye çalışmıştır. Teorik model birçok değişken ve firma performansı arasındaki pozitif ilişkiler öngörmektedir; bu değişkenler iş bağlantıları, destek bağlantıları, girişimci yönelim ve stratejik öğrenme yetisidir. Ayrıca, bu ilişkilerin kümelenmenin moderatör etkisi nedeniyle daha artacağı varsayılmıştır. Dokuz Türk kümelenmesinde yer alan ve

\footnotetext{
* This study is based on the Ph.D. dissertation thesis, Competitive Advantage and Clusters: Evidence from Textile, Wearing Apparel, Carpet, Automotive, Tourism, and Furniture Clusters in Turkey, completed at Boğaziçi University, Turkey in 2015. The author wishes to thank Prof. Özlem Öz for her guidance and suggestions.

** Nigar Çağla Mutlucan is an Assistant Professor in the Department of Aviation Management at Beykoz University, Vatan Caddesi, No: 69, 34805, Kavacık, Beykoz, İstanbul, Turkey. E-mail: nigarcaglamutlucan@beykoz.edu.tr
} 
anket yollanmış 160 firmadan elde edilen verilerin PLS modeli analizi sonucunda, sadece girişimci yönelim ve destek bağlantılarının firma performansını anlamlı ve pozitif şekilde etkilediği bulunmuştur.

Anahtar kelimeler: kümelenme, rekabetçi avantaj, performans, girişimci yönelim, iş bağlantıları, destek bağlantılart.

JEL siniflandirmast: L26, D85, L25, L14.

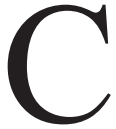

lusters had already been a topic of interest to academics and practitioners before Porter (1990) drew attention to its beneficial effects with his diamond framework. Our review of the cluster literature reveals that it includes many studies at the cluster-level of analysis and that very few studies analyze firm-level characteristics that may help firms improve their performance.

In general, the firm-level characteristics that are presumed to affect the relationship between clusters and firm performance are firm size and age. Additionally, some studies examine the firm resources that differentiate high- from low-performing cluster firms. Therefore, Saric's study (2012), which is one of the few studies that try to bring the cluster discourse back to the firm, emphasizes that there is a need to explore the mechanisms that produce benefits for individual firms within the clusters.

Following Saric's (2012) call for more firm-level research to fill the gap in the literature, the present study tries to build and test a model to explore the firm characteristics that lead to performance differences among firms. Hence, the research question is as follows: How do firms create and defend competitive advantages through clusters? This study specifically examines the effects of business ties, support ties, entrepreneurial orientation and strategic learning capability on firm performance. Moreover, we check whether or not the cluster construct has a moderating effect on the relationship between each construct and firm performance.

In this paper, the definition of clusters is adopted from Rocha and Sternberg's (2005: 270) study: "a geographically proximate group of firms and associated institutions in related industries, linked by economic and social interdependencies".

Several provinces of Turkey are chosen for the test of the theoretical model after the calculation of their location quotients, which will be elaborated on in the methodology section. The clusters chosen to this end, are as follows: the wearing apparel cluster in Istanbul, textile clusters in Denizli and Bursa, the carpet cluster in Gaziantep, the automotive cluster in Bursa, furniture clusters in Kayseri and Ankara, and tourism clusters in Antalya and Muğla. Three of these clusters, the automotive cluster in Bursa, the towel and bathrobe cluster in Denizli, and the carpet cluster in Gaziantep, have already been qualitatively studied by Oz $(1999,2004)$, but without quantitative data about them. These provinces are known to be successful cluster examples in Turkey though they have different degrees of agglomeration. Our study includes six new clusters, along with the three clusters qualitatively examined by Oz $(1999,2004)$. Two tourism clusters in Antalya and in Muğla are included in the sample because cluster literature focuses 
generally on manufacturing industries. Moreover, tourism clusters are studied as case studies (Breda et al., 2006; Porter, 2008). We wanted to offer a thorough research on clusters by adding service clusters in the sample of a quantitative study.

The study includes a literature review on the origins of clusters, Porterian clusters, and the impact of clusters on firm performance. The following section presents the hypotheses of this study. The research methodology of the empirical study and the measurement of the constructs are explained in the next section. Then, Partial Least Squares - SEM analyses are performed, and the results are discussed subsequently. The final section provides the conclusions, limitations and implications of the study. The questionnaire is given in the Appendix.

\section{Literature Review}

\section{Origins of Clusters}

Since the 1990s, academics and practitioners have paid an increasing amount of attention to clusters. However, the pioneer in this field was Alfred Marshall with his 1890 classic, the Principles of Economics. Marshall's focus was on industrial districts where small and medium sized firms throve on external economies of localized specialization (Marshall, 1927). While Michael Porter and business scholars put clusters in the limelight in the 1990s, several Italian economists had already been interested in industrial district formation (Becattini, 1989; 1990) or districtualization processes (Varaldo and Ferucci, 1996; Lazzeretti, 2003). What makes Becattini (1990) and his colleagues' work different from Marshall's is the description of the industrial district; besides being an economic entity, it has also socio-cultural characteristics. Moreover, Piore and Sabel (1984) had synthesized the Neo-Marshallian Italian Research and announced a "second industrial divide", which involved a shift from mass production to the "flexible specialization" of industrial districts (Asheim et al., 2006).

Scholars from The Californian School (Scott, 1988; Storper, 1997) were also interested in clusters. They investigated technology districts in southern and central California that were composed of geographically concentrated, specialized and vertically disintegrated networks of firms and institutions. Their study was basically based on a transaction cost analysis. The Californian School extended the work of the Italian Industrial Districts School by including firms of all sizes, different sectors, and regions of different historical and institutional contexts, but it only scrutinized measurable traded interdependencies (Saric, 2012). Therefore, Storper (1997) focused on untraded interdependencies; these are socially constructed assets, specific to a region, such as conventions, norms and, informal rules, that lead to transaction cost savings (Saric, 2012).

Krugman's new trade theory (1991) considers geographical concentration as the result of increasing returns that stem from economies of specialization and scale at the plant level. However, Krugman deliberately ignores technological spillovers among firms, as they are invisible and therefore, untraceable and unmeasurable according to him. Finally, the neo-Schumpeterian and evolutionary economics argued that innovation 
and entrepreneurship can be described as specially embedded and localized processes. Their focus is on successful high-tech districts and clusters.

\section{Porterian Clusters}

According to Porter (2008: 213), "[C]lusters are geographic concentrations of interconnected companies, specialized suppliers, service providers, firms in related industries, and associated institutions (for example, universities, standards agencies, trade associations) in a particular field that compete but also cooperate". Clusters are the linchpin of Porter's theory as they are a manifestation of the diamond framework. He posits that the competitive advantage is not located inside a given company or even inside its industry, it is rather located in the "locations of its business units" (Porter, 2008: 214).

Clusters can be composed of a single city, a state, a country or a network of neighboring countries. Porter (2008) emphasizes the effects of clusters on competition, they affect competition in three ways: they increase the productivity of local firms or industries, they increase their capacity for innovation, which leads to productivity growth, and finally, they prompt new business formation that supports innovation and expands the cluster. Moreover, these three influences of clusters on competition can be enhanced by "personal relationships, face-to-face communication, and interaction among networks of individuals and institutions" (Porter, 2008: 229).

\section{Clusters and Firm Performance}

Although cluster studies are generally conducted at the cluster-level of analysis; there are some studies that pay attention to the characteristics and performance of the firms that operate from within the clusters. According to Gilbert et al. (2008), firms located within geographic clusters absorb more knowledge from the local environment and have higher growth and innovation performance. However, Kukalis' (2010) study show that clustered and non-clustered firms are not significantly different in the early stages of the industry life cycle. In addition, isolated firms outperform clustered firms in the late stages of the industry life cycle. Wennberg and Lindqvist's (2010) findings corroborate previous findings; they assert that especially the newly started entrepreneurial firms can reap the economic benefits that clusters offer to all firms. Li and Geng (2012) find that cluster firms have higher perceptions of shared resources compared to non-cluster firms and that shared resources help cluster firms have better performance. Again, these results are in congruence with the findings of past research that draw attention to the performance advantages of cluster firms compared to non-cluster firms.

There are a few studies that investigate firm characteristics, other than firm size and firm age. Zhang and Li (2008) find that managerial ties and firm resources - independently and in combination - contribute to the market performance of the firms within the clusters. Liao (2010) finds that the interaction effect of resources and clustering has a positive effect on firm performance. Saric's (2012) findings confirm the results of previous studies that assert the positive effect of clusters on firm performance. Overall, these studies demonstrate that some characteristics of firms have a positive effect on 
their performance and that clustering enhances this positive effect.

\section{Hypotheses}

As the literature review indicates, cluster studies are mostly conducted at the cluster level except for the very few studies that focus on a limited number of firm characteristics, such as firm size, firm age, and firm resources, that lead to performance differences. Recently, Saric (2012) drew attention to the lack of research on firm characteristics that create performance differences among cluster firms. Apparently, there is a gap in this area: there are more firm characteristics that affect the performance of the firms which operate from within the clusters. Therefore, managerial ties (business ties and support ties), entrepreneurial orientation and strategic learning constructs are deemed appropriate to be included in this study.

Managerial ties constitute a manager's social capital that can promote firm performance. Peng and Luo's (2000) findings indicate that managers' interpersonal ties with top executives at other firms and with government officials can increase the performance of Chinese organizations. Moreover, ties with officials play a more important role than ties with managers at other firms do in firm performance. Acquaah (2007) replicates Peng and Luo's (2000) research by using data from Ghana. He discovers that organizational performance can be enhanced by building social capital that stems from managerial networking and social relationships with top managers at other firms, government officials, and community leadership. The findings corroborate those deriving from Peng and Luo's (2000) research. However, they contradict Peng and Luo's (2000) findings as social capital from top managers at other firms in Ghana prevails over that from government officials.

In short, managerial ties, both with managers at other firms and with government officials, have been argued to affect firm performance. In this paper, managerial ties will be classified under two categories following Zhang and Li (2008): ties with executives at other firms, such as suppliers, buyers, and competitors will be classified as business ties and non-business ties with other supportive institutions, such as government and business associations will be construed as support ties. Therefore, our first hypothesis is formulated as follows:

H1: The strength of a firm's business ties will a have positive effect on firm performance.

When describing the Turkish business environment, one should recognize that the state played a central role in its industrialization; state-created big business groups have dominated the economy for a long time. The presence of retired/resigned bureaucrats from key public organizations sitting on boards of directors is a means of establishing good relationships with governmental institutions by using their connections for riskreduction and opportunity-seizing (Berkman and Özen, 2008). The Turkish state used to change major economic policies without due notice, creating an uncertain economic environment for businessmen. Consequently, Turkish businessmen strove to connect 
with bureaucrats and politicians by seeking individually, or through networking, the support of influential bureaucrats (Oba and Semerciöz, 2005). Though Turkey achieved a fast and thorough privatization and developed market regulations after the financial crisis in 2001, there is still a state-coordinated business system. This context leads to the second hypothesis of this study.

H2: The strength of a firm's support ties will a have positive effect on firm performance.

Clusters have also been studied as environments that enhance the effects of managerial ties on firm performance. Previous findings of studies in a Chinese context affirm that managerial ties have a positive influence on the performance of cluster firms (Zhang and Li, 2008; Li and Geng, 2012). As for Turkey, many clusters are city-based and sociocultural environment plays an important role for cluster firms. The partners of spin-offs are generally relatives or fellow townsmen (Oz, 2004). Therefore, social networking is supposed to play an important role in the functioning of clusters and in the performance of firms in Turkey.

H3: Cluster environment positively moderates the relationship between business ties and firm performance in such a way that the positive relationship will be more salient in the presence of a cluster environment.

H4: Cluster environment positively moderates the relationship between support ties and firm performance in such a way that the positive relationship will be more salient in the presence of dense support relationships in the cluster environment.

Nevertheless, firm-level characteristics, different than size and age, should also be explored to explain performance differentials among cluster-firms. Entrepreneurship theory can shed light on how firms explore impermanent economic opportunities through clusters. In general, three dimensions of entrepreneurial orientation have been used in the literature: innovativeness, risk taking, and proactiveness.

Innovativeness is "the predisposition to engage in creativity and experimentation through the introduction of new products/services as well as technological leadership via R\&D in new processes" (Rauch et al., 2009: 763). Risk taking involves "taking bold actions by venturing into the unknown, borrowing heavily, and/or committing significant resources to ventures in uncertain environments" (Rauch et al., 2009: 763). Proactiveness is an "opportunity-seeking, forward-looking perspective characterized by the introduction of new products and services ahead of the competition and acting in anticipation of future demand" (Rauch et al., 2009: 763). Businesses with entrepreneurial orientation can explore new opportunities that help them outperform their competitors.

As mentioned previously, entrepreneurial orientation (EO) has been intensively studied in entrepreneurship research. Rauch et al. (2009) reviewed fifty-one published studies in a meta-analysis including 14,259 companies and found a positive and moderately large relationship between EO and firm performance. This leads to the fifth hypothesis:

H5: A firm's entrepreneurial orientation will have a positive effect on firm 


\section{performance.}

Though EO has not been a well-studied subject in cluster literature, its effects on firm performance and its impact on networks and relationships have been examined by several scholars. These studies reveal that firms with an EO perform better in environments marked by rivalry, uncertainty and frequent changes (Zahra and Covin, 1995; Wiklund and Shepherd, 2005; Zahra and Garvis, 2000; Dimitratos et al., 2004).

Saric (2012) uses the EO concept in the cluster context. He finds that firms with an entrepreneurial orientation and a well-developed cluster-capability are more successful in the competition.

As for clusters in Turkey, Oz (2004) cites entrepreneurial outlook as one of the common characteristics of competitive clusters. In sum, firms that exhibit an EO are more adept at exploring opportunities and procuring and combining the necessary resources to outperform their competitors. Therefore, clusters provide a propitious environment for entrepreneurial firms to benefit from the intensity of the information flows and network alliances.

H6: Cluster environment positively moderates the relationship between EO and firm performance in such a way that the positive relationship between EO and firm performance will be more salient in the presence of a cluster environment.

Another construct that can help understand the firm-level characteristics that cause different levels of performance is strategic learning. Siren et al. (2012) describe strategic learning as a cyclical process in which strategic knowledge diffuses from the individual to the group and finally to the organizational level and back again to facilitate individual learning. Siren et al. (2012) developed a model of strategic learning including three underlying dimensions: strategic knowledge distribution, interpretation, and implementation. In the strategic knowledge distribution dimension, the person with the strategic knowledge shares it through interactions between individuals within and across organizational units. In the strategic knowledge interpretation dimension, this knowledge should be interpreted to create a shared understanding. Finally, in the strategic knowledge implementation dimension, the new strategic knowledge is etched in the organizational memory by means of organizational systems, structures, procedures, and routines. Their research on 206 Finnish software firms show that strategic learning fully mediates the relationship between exploration, exploitation, and profit performance; therefore, both types of strategies improve profit performance. In summary, strategic learning capability can have a positive impact on firm performance. In this context, hypothesis seven is presented.

H7: A firm's strategic learning capability will have a positive effect on firm performance.

Surprisingly, the strategic learning concept has not been studied in the cluster context so far. Yet, clusters are environments where dynamic capabilities, such as strategic 
learning, are needed to outperform competitors. To keep pace with the dynamism of their environment, firms should create the free flow of the strategic knowledge contained within their departments or in their members' memory; it should become part of the organizational memory. Consequently, organizations will review the procedural routines concerning their innovation process at the corporate level and outperform their competitors by sensing and responding to the opportunities within clusters. In a nutshell, strategic learning helps organizations incorporate knowledge more easily, realize a faster opportunity capitalization and achieve a better profit performance. (Siren et al., 2012). Therefore,

H8: Cluster environment positively moderates the relationship between strategic learning capability and firm performance in such a way that the positive relationship between strategic learning and firm performance will be more salient in the presence of a cluster environment.

Figure 1 depicts the theoretical model.

Figure 1.

\section{The Theoretical Model}

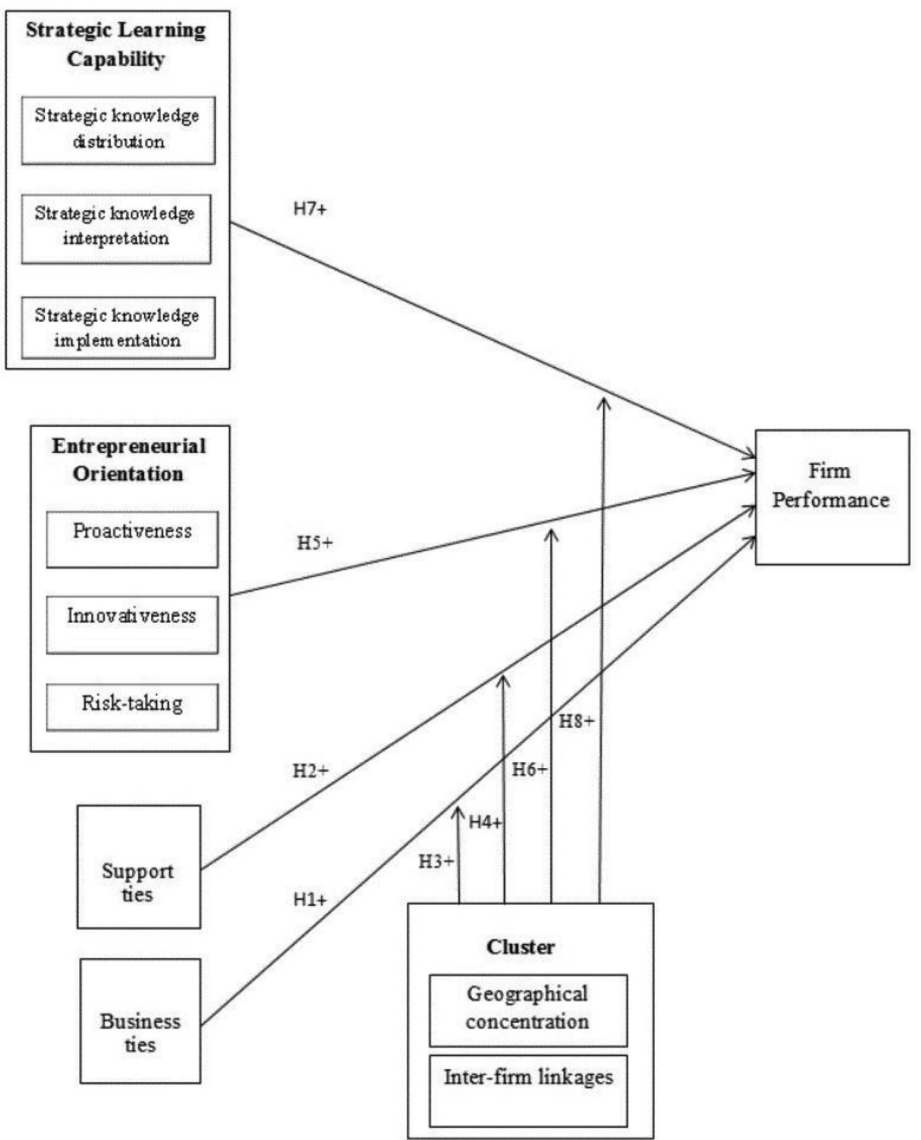




\section{Research Methodology and Measurement}

A survey was conducted in clusters in Istanbul (wearing apparel), Bursa (textile and automotive), Kayseri (furniture), Ankara (furniture), Denizli (textile), Gaziantep (carpet), Muğla (tourism), and Antalya (tourism). These cities are chosen according to their location quotients. LQ is a way of quantifying how concentrated an industry is in a region compared to a larger geographic area. Industry LQs are calculated by comparing the industry's share of regional employment with its share of national employment. The questionnaires were sent to C-level executives. C-level means high-ranking executive titles within an organization, the letter $\mathrm{C}$ standing for chief. They are supposed to be highly knowledgeable about their firms' overall goals, past, present, and future directions as well as their rivals, markets and customers.

\section{Measurement of the Constructs}

In the present study, some of the measures are taken from prior studies verbatim, and some of them are adapted to the Turkish context; they are all reported in Table 3 . All variables, including one control variable (environmental dynamism), are measured on five-point Likert scales ranging from 1 to 5.

The cluster scale is taken from Saric (2012). The cluster construct is conceived as a second-order construct, and it has two dimensions: geographical concentration and inter-firm linkages

The entrepreneurial orientation (EO) scale is also taken from Saric (2012). The entrepreneurial orientation construct is conceived as a second-order construct and it has three dimensions: proactiveness, innovativeness, risk-taking.

For business ties, the respondents evaluated the questions on a five-point scale, ranging from very little to very much, with items taken from Li et al. (2008). As for support ties, the first item is adapted from Li et al. (2008) and the other items were created by the author of the study.

The strategic learning scale is taken from Siren et al. (2012). Finally, the performance scale items are taken from Saric's (2012) study: respondents are asked to use their judgment instead of stating actual financial data. Subjective measurement of performance is often used in the Turkish context (Tatoglu and Glaister, 1998; Kula, 2005). In fact, Covin et al. (1994) and Venkatraman and Ramanujam (1986) report that the performance perceptions of managers and objective performance measures are in congruence.

Control variables will be firm age, firm size, and environmental dynamism. The three items are taken from Siren et al.’s (2012) study.

\section{Data Collection}

A survey was conducted to gather quantitative data. The questionnaire used existing measures with some minor changes in order to adapt them to the Turkish business environment.

As the questionnaire focuses on strategic issues, the targeted respondents were Clevel Turkish managers in the previously mentioned nine clusters. The questionnaire was translated using the back-translation method. A pre-test in five Turkish companies 
created the opportunity to test the questionnaire's comprehensibility. The questionnaire was sent with an email written in Turkish. The data collection process took seven months, from February to August 2015. The contact information of the cluster firms was extracted from the databases of the chambers of commerce and/or industry of the chosen clusters. Respondents were contacted twice; firms that had only a fax number were sent two faxes, the second of which was sent one week after the first one. In total, it was possible to reach 4,676 firms, from whom 167 responses were obtained. Two firms turned out to be working in the construction industry, so they were removed from the sample.

In the final step, the data examination process was carried out. Normality checks were performed to check for extremely non-normal data. The variable size had extreme skewness (5.377) and kurtosis (33.624) values; therefore, log transformation was applied, and skewness and kurtosis values decreased to 0.215 and -0.190 , respectively. Two cases, identified as outliers, were removed from the sample. As for missing values, there were no cases with missing values exceeding $15 \%$ of the observation, but three cases were eliminated because of low quality and inconsistent responses. There were only five cases with missing values, and respondents were contacted immediately after they returned the questionnaire to get answers for the missing few items. Finally, there were no missing values, the final sample consisted of 160 valid responses, bringing the total response rate to $3.42 \%$. The minimum sample number is calculated as follows: the most complex endogenous construct is the dependent variable performance, it has 12 exogenous constructs; according to the 10 times rule, the minimum sample is 120 . Therefore, the sample is enough to do a PLS path analysis.

The final sample was tested for Common Method Bias and Nonresponse Bias. This study has a cross-sectional survey design; therefore, Common Method Bias may arise as responses by a single source can give false correlation values between two or more variables. To eliminate this bias from happening, anonymity was ensured, and dependent and independent variables were put into different parts of the questionnaire. Also, the Harman-Single-Factor-Test excludes the existence of Common Method Bias. The principal component factor analysis indicated four distinct factors with eigenvalue greater than 1.0. The four factors together accounted for $66 \%$ of the total variance; the first factor did not represent a majority of the variance $(36 \%)$. Hence, no general factor is apparent.

Lastly, the final sample was tested for Nonresponse Bias. It was divided in two groups; the first group was composed of responses received after the first email or fax, whereas the second group included those who answered after the second email or fax. This second group are considered the late respondents. No significant differences were found in the key variables when the two groups were compared. Thus, we concluded there is no significant Nonresponse Bias.

The average firm size was 187 employees, while the median company had 67 employees. The minimum firm size was 3, while the maximum firm size was 3,500 employees. Nearly half of the companies had up to 50 employees. Table 1 and Table 2 present the number of firms per cluster according to firm size. They show that firms 
with up to 9 employees had a very low response rate to the survey while firms with 10 to 49 and 50 to 249 employees had the highest one in total. As for firms with more than 250 employees, half of these firms responded in Ankara and Muğla, and at least two firms responded in other clusters. In sum, the majority of the respondents were small and medium-sized firms in this study. However, Table 1 and Table 2 reveal that micro-firms (with up to 9 employees) make up more than half of the firm population in the chosen clusters (93\% in Ankara), except for the micro-firms in Gaziantep that form $47 \%$ of the firm population. Therefore, there is a representativeness problem for these firms in the sample. This might be the result of a self-selection bias as the survey was conducted by means of emails and faxes. The results of this study should be evaluated keeping this bias in mind.

Table 1

Number of Firms per Cluster According to Firm Size (2015)

\begin{tabular}{l|r|r|r|r|r|r|r|r|r|r} 
& \multicolumn{4}{|c|}{ Furniture } & \multicolumn{2}{|c|}{ Automotive } & \multicolumn{3}{|c}{ Carpet } & \multicolumn{3}{c}{ Wearing Apparel } \\
\hline Firm Size & Ankara_T & Ankara & Kayseri_T & Kayseri & Bursa_T & Bursa & Gaziantep_T & Gaziantep & İstanbul_T & İstanbul \\
\hline $1-9$ & 4717 & 2 & 1556 & 0 & 463 & 3 & 168 & 0 & 25449 & 0 \\
\hline $10-49$ & 298 & 3 & 258 & 12 & 174 & 6 & 92 & 1 & 5302 & 8 \\
\hline $50-249$ & 45 & 4 & 69 & 7 & 92 & 4 & 72 & 6 & 1067 & 9 \\
\hline $250+$ & 8 & 3 & 13 & 2 & 38 & 5 & 25 & 2 & 181 & 2 \\
\hline Total & 5068 & 12 & 1896 & 21 & 767 & 18 & 357 & 9 & 31999 & 19 \\
\hline
\end{tabular}

T: Total

Table 2

Number of Firms per Cluster According to Firm Size (2015 - Continued)

\begin{tabular}{l|r|r|r|r|r|r|r|r} 
& \multicolumn{5}{|c|}{ Textile } & \multicolumn{4}{c}{ Tourism } \\
\hline Firm Size & Bursa_T & Bursa & Denizli_T & Denizli & Muğla_T & Muğla & Antalya_T & Antalya \\
\hline $1-9$ & 2227 & 4 & 1777 & 0 & 1073 & 4 & 754 & 0 \\
\hline $10-49$ & 599 & 19 & 342 & 4 & 239 & 5 & 310 & 3 \\
\hline $50-249$ & 223 & 8 & 114 & 7 & 67 & 5 & 181 & 9 \\
\hline $250+$ & 38 & 2 & 23 & 4 & 5 & 2 & 75 & 5 \\
\hline Total & 3087 & 33 & 2256 & 15 & 1384 & 16 & 1320 & 17 \\
\hline
\end{tabular}

T: Total

\section{Partial Least Squares - SEM Analyses}

The present study uses the partial least squares (PLS) approach. The model will be assessed by SmartPLS 3.2.1. 
As for the operationalization of the latent variables, a measurement model can have formative or reflective indicators, or include both, depending on the nature of the latent variables. Also, constructs can be designed as higher-order constructs with multiple dimensions of lower-order constructs. In this study, the constructs cluster and EO are defined as Type II (reflective first-order, formative second-order) second-order constructs and strategic learning capability is defined as a Type I (reflective first-order, reflective second-order) second-order construct.

Reflective measurement models are evaluated by calculating composite reliability (CR) to evaluate internal consistency, individual indicator reliability, and average variance extracted (AVE) to evaluate convergent validity. Also, discriminant validity is examined by using the Fornell-Larcker criterion and cross loadings.

In exploratory research, the threshold for composite reliability values changes between 0.60 and 0.70 , but in case of a more advanced research, values greater than 0.70 are regarded as satisfactory. A common rule of thumb is that the standardized outer loadings should be 0.708 or higher. In general, indicators with outer loadings between 0.40 and 0.70 can be removed from the scale if deleting the indicator leads to an increase in the composite reliability (or the AVE) above the suggested threshold value. However, indicators with very low outer loadings (below 0.40) should always be deleted. In the present study, reliability and convergent validity are ensured as the composite reliability and AVE values are above their recommended thresholds.

Table 3

Means, Standard Deviations (SDs), Outer Loadings, AVE and Composite Reliability

\begin{tabular}{|c|c|c|c|}
\hline Constructs and items (all measured on five-point Likert scales) & Mean & SD & $\begin{array}{l}\text { Outer } \\
\text { Loading }\end{array}$ \\
\hline Firm age & 19.59 & 11.82 & \\
\hline Firm size & 186.96 & 419.362 & \\
\hline \multicolumn{4}{|l|}{ Geographical concentration (AVE: 0.529; CR: 0.761) } \\
\hline \multicolumn{4}{|l|}{ Please compare your industry to other industries in your region } \\
\hline $\begin{array}{l}\text { The number of companies operating in our industry compared to } \\
\text { the number of companies operating in other industries }\end{array}$ & 4.39 & 0.825 & 0.473 \\
\hline $\begin{array}{l}\text { The number of people employed in our industry compared to the } \\
\text { number of people employed by other industries }\end{array}$ & 4.06 & 0.956 & 0.812 \\
\hline $\begin{array}{l}\text { The percentage our industry contributes to the regional gross } \\
\text { value added compared to the total regional gross value added }\end{array}$ & 3.84 & 1.027 & 0.838 \\
\hline \multicolumn{4}{|l|}{ Inter-firm linkages (AVE: 0.551; CR: 0.785) } \\
\hline \multicolumn{4}{|l|}{$\begin{array}{l}\text { To what extent do you agree or disagree with the following } \\
\text { statements? }\end{array}$} \\
\hline $\begin{array}{l}\text { Our region is home to a large number of suppliers and potential } \\
\text { customers }\end{array}$ & 4.46 & 0.76 & 0.628 \\
\hline
\end{tabular}




\begin{tabular}{|c|c|c|c|}
\hline Constructs and items (all measured on five-point Likert scales) & Mean & SD & $\begin{array}{l}\text { Outer } \\
\text { Loading }\end{array}$ \\
\hline $\begin{array}{l}\text { We have built networks and alliances with our local business } \\
\text { partners }\end{array}$ & 3.03 & 1.362 & 0.801 \\
\hline $\begin{array}{l}\text { Our employees regularly participate in relevant local industry } \\
\text { events }\end{array}$ & 2.44 & 1.287 & 0.787 \\
\hline $\begin{array}{l}\text { In our local business environment, it is common that employees } \\
\text { who switch jobs move from one local company to another }\end{array}$ & eliminated & eliminated & eliminated \\
\hline \multicolumn{4}{|l|}{ Proactiveness (AVE: 0.702; CR: 0.903) } \\
\hline \multicolumn{4}{|l|}{$\begin{array}{l}\text { To what extent do you agree or disagree with the following } \\
\text { statements? }\end{array}$} \\
\hline $\begin{array}{l}\text { Overall, my firm regularly scans the environment and gathers } \\
\text { information from our local business partners to seek and identify } \\
\text { new opportunities }\end{array}$ & 3.55 & 1.051 & 0.737 \\
\hline $\begin{array}{l}\text { In general, the top managers of my firm initiate pre-emptive } \\
\text { actions in response to perceived opportunities which competitors } \\
\text { then respond to }\end{array}$ & 3.51 & 1.099 & 0.844 \\
\hline $\begin{array}{l}\text { We are very often the first to introduce new products or services to } \\
\text { our customers }\end{array}$ & 3.54 & 1.197 & 0.864 \\
\hline In general, my firm is eager to be a leader rather than a follower & 3.81 & 1.139 & 0.897 \\
\hline \multicolumn{4}{|l|}{ Innovativeness (AVE: 0.984 ; CR: 0.992) } \\
\hline \multicolumn{4}{|l|}{$\begin{array}{l}\text { To what extent do you agree or disagree with the following } \\
\text { statements? }\end{array}$} \\
\hline $\begin{array}{l}\text { During the past three years my firm has marketed very many new } \\
\text { lines of products and services }\end{array}$ & 3.61 & 1.229 & 0.992 \\
\hline Changes in product and service lines have been quite dramatic & 3.46 & 1.355 & 0.992 \\
\hline \multicolumn{4}{|l|}{ Risk-taking (AVE: 0.851; CR: 0.920) } \\
\hline \multicolumn{4}{|l|}{ In my firm... } \\
\hline $\begin{array}{l}\text {...managers have a strong proclivity for high-risk projects (with } \\
\text { chances of very high returns) }\end{array}$ & 3.21 & 1.166 & 0.927 \\
\hline $\begin{array}{l}\text {...managers believe that owing to the nature of the environment, } \\
\text { bold wide-ranging acts are necessary to achieve the firm's } \\
\text { objectives }\end{array}$ & 3.55 & 1.08 & 0.918 \\
\hline \multicolumn{4}{|l|}{ Business ties (AVE: 0.615; CR: 0.827) } \\
\hline \multicolumn{4}{|l|}{$\begin{array}{l}\text { To what extent have you utilized personal ties, networks, and } \\
\text { connections with the top executives }\end{array}$} \\
\hline ... at supplier firms during the past three years? & 4.04 & 1.018 & 0.754 \\
\hline ... at buyer firms during the past three years? & 4.06 & 0.979 & 0.823 \\
\hline ...at competitor firms during the past three years? & 2.83 & 1.231 & 0.769 \\
\hline \multicolumn{4}{|l|}{ Support ties (AVE: 0.526; CR: 0.884) } \\
\hline $\begin{array}{l}\text { To what extent have you utilized personal ties, networks, and } \\
\text { connections with }\end{array}$ & & & \\
\hline
\end{tabular}




\begin{tabular}{|c|c|c|c|}
\hline Constructs and items (all measured on five-point Likert scales) & Mean & SD & $\begin{array}{l}\text { Outer } \\
\text { Loading }\end{array}$ \\
\hline political persons from the government during the past three years? & 1.46 & 0.896 & 0.560 \\
\hline people from educational institutions during the past three years? & 2.31 & 1.244 & 0.669 \\
\hline officials in municipalities during the past three years? & 2.19 & 1.353 & 0.827 \\
\hline officials in state banks during the past three years? & 2.31 & 1.383 & 0.604 \\
\hline officials in tax bureaus during the past three years? & 2.39 & 1.392 & 0.798 \\
\hline officials in chambers of commerce during the past three years? & 2.76 & 1.443 & 0.838 \\
\hline officials in chambers of industry during the past three years? & 2.62 & 1.453 & 0.730 \\
\hline officials in cooperatives during the past three years? & eliminated & eliminated & eliminated \\
\hline \multicolumn{4}{|l|}{ Strategic knowledge distribution (AVE: 0.658 ; CR: 0.906) } \\
\hline \multicolumn{4}{|l|}{$\begin{array}{l}\text { To what extent do you agree or disagree with the following } \\
\text { statements? }\end{array}$} \\
\hline Within our firm, sharing strategic information is the norm & 3.07 & 1.432 & 0.814 \\
\hline $\begin{array}{l}\text { Within our firm, strategically important information is easily } \\
\text { accessible to those who need it most }\end{array}$ & 3.07 & 1.344 & 0.812 \\
\hline $\begin{array}{l}\text { Representatives from different departments meet regularly to } \\
\text { discuss new strategically important issues }\end{array}$ & 3.31 & 1.213 & 0.790 \\
\hline $\begin{array}{l}\text { Within our firm, strategically important information is actively } \\
\text { shared between different departments }\end{array}$ & 3.34 & 1.144 & 0.877 \\
\hline $\begin{array}{l}\text { When one department obtains strategically important } \\
\text { information, it is circulated to other departments }\end{array}$ & 3.42 & 1.231 & 0.759 \\
\hline \multicolumn{4}{|l|}{ Strategic knowledge interpretation (AVE: 0.721; CR: 0.928) } \\
\hline \multicolumn{4}{|l|}{$\begin{array}{l}\text { To what extent do you agree or disagree with the following } \\
\text { statements? }\end{array}$} \\
\hline $\begin{array}{l}\text { When faced with new strategically important information, our } \\
\text { managers usually agree on how the information will impact our } \\
\text { firm }\end{array}$ & 3.63 & 0.988 & 0.744 \\
\hline $\begin{array}{l}\text { In meetings, we seek to understand everyone's point of view } \\
\text { concerning new strategic information }\end{array}$ & 3.79 & 0.974 & 0.899 \\
\hline $\begin{array}{l}\text { Groups are prepared to rethink decisions when presented with } \\
\text { new strategic information }\end{array}$ & 3.57 & 1.013 & 0.877 \\
\hline $\begin{array}{l}\text { When confronting new strategic information, we are not afraid } \\
\text { to critically reflect on the shared assumptions we have about our } \\
\text { organization }\end{array}$ & 3.76 & 1.043 & 0.848 \\
\hline $\begin{array}{l}\text { We often collectively question our own biases about the way we } \\
\text { interpret new strategic knowledge }\end{array}$ & 3.64 & 1.031 & 0.870 \\
\hline \multicolumn{4}{|l|}{ Strategic knowledge implementation (AVE: 0.674; CR: 0.892) } \\
\hline \multicolumn{4}{|l|}{$\begin{array}{l}\text { To what extent do you agree or disagree with the following } \\
\text { statements? }\end{array}$} \\
\hline $\begin{array}{l}\text { Strategic knowledge gained by working groups is used to improve } \\
\text { products, services, and processes }\end{array}$ & 3.9 & 0.985 & 0.847 \\
\hline
\end{tabular}




\begin{tabular}{|c|c|c|c|}
\hline Constructs and items (all measured on five-point Likert scales) & Mean & SD & $\begin{array}{l}\text { Outer } \\
\text { Loading }\end{array}$ \\
\hline $\begin{array}{l}\text { The decisions we make according to any new strategic knowledge } \\
\text { are reflected in changes to our organizational systems and } \\
\text { procedures }\end{array}$ & 3.69 & 1.052 & 0.846 \\
\hline $\begin{array}{l}\text { Strategic knowledge gained by individuals has an effect on the } \\
\text { organization's strategy }\end{array}$ & 3.52 & 1.046 & 0.768 \\
\hline $\begin{array}{l}\text { Recommendations by groups concerning the use of strategic } \\
\text { knowledge are adopted by the organization }\end{array}$ & 3.44 & 0.956 & 0.820 \\
\hline \multicolumn{4}{|l|}{ Profitability (AVE: 0.886; CR: 0.959) } \\
\hline \multicolumn{4}{|l|}{$\begin{array}{l}\text { Please assess your firm's performance relative to your competitors } \\
\text { over the three years 2012/2013/2014 in terms of }\end{array}$} \\
\hline ...return on investment & 3.11 & 1.144 & 0.913 \\
\hline ...profit margin & 3.01 & 1.138 & 0.964 \\
\hline ...net profits & 2.97 & 1.107 & 0.947 \\
\hline \multicolumn{4}{|l|}{ Sales performance (AVE: 0.929 ; CR: 0.963 ) } \\
\hline \multicolumn{4}{|l|}{$\begin{array}{l}\text { Please assess your firm's performance relative to your competitors } \\
\text { over the three years 2012/2013/2014 in terms of }\end{array}$} \\
\hline ...sales volume & 3.36 & 1.135 & 0.962 \\
\hline ...growth in sales volume & 3.36 & 1.189 & 0.966 \\
\hline \multicolumn{4}{|l|}{ Environmental dynamism (AVE: 0.778; CR: 0.875) } \\
\hline \multicolumn{4}{|l|}{$\begin{array}{l}\text { How would you assess your firm's business environment with the } \\
\text { following statements? }\end{array}$} \\
\hline Product demand is hard to forecast & 2.92 & 1.216 & 0.844 \\
\hline Customer requirements and preferences are hard to forecast & 2.86 & 1.281 & 0.919 \\
\hline $\begin{array}{l}\text { My industry is very unstable with huge change resulting from } \\
\text { major economic, technological, social, or political forces }\end{array}$ & eliminated & eliminated & eliminated \\
\hline
\end{tabular}

Table 4 presents the factor loadings of the strategic learning capability construct.

Table 4

Factor Loadings of the Strategic Learning Capability Construct

\begin{tabular}{l|l|l} 
Dimensions & Factor Loadings & P value \\
\hline Strategic learning capability $\rightarrow$ Strategic knowledge distribution & $0.789^{* * *}$ & .000 \\
\hline Strategic learning capability $\rightarrow$ Strategic knowledge interpretation & $0.927^{* * *}$ & .000 \\
\hline Strategic learning capability $\rightarrow$ Strategic knowledge implementation & $0.902^{* * *}$ & .000
\end{tabular}
${ }^{*} p<.10,{ }^{* *} p<.05,{ }^{* *} p<.01$

\section{Test for Discriminant Validity on the Construct Level}

If an indicator's loading on a construct is higher than all of its cross loadings with other constructs, discriminant validity is established. The examination of the loadings 
and the cross-loadings for every indicator in the model shows that there is no violation.

Discriminant validity on the construct level was assessed using the Fornell-Larcker criterion across all first order constructs. The square root of each construct's AVE is greater than its highest correlation with any other construct. Overall, cross-loadings as well as the Fornell-Larcker criterion provide evidence for the constructs' discriminant validity (see Table 5).

Table 5.

Discriminant Validity on the Construct Level with Fornell-Larcker Criterion

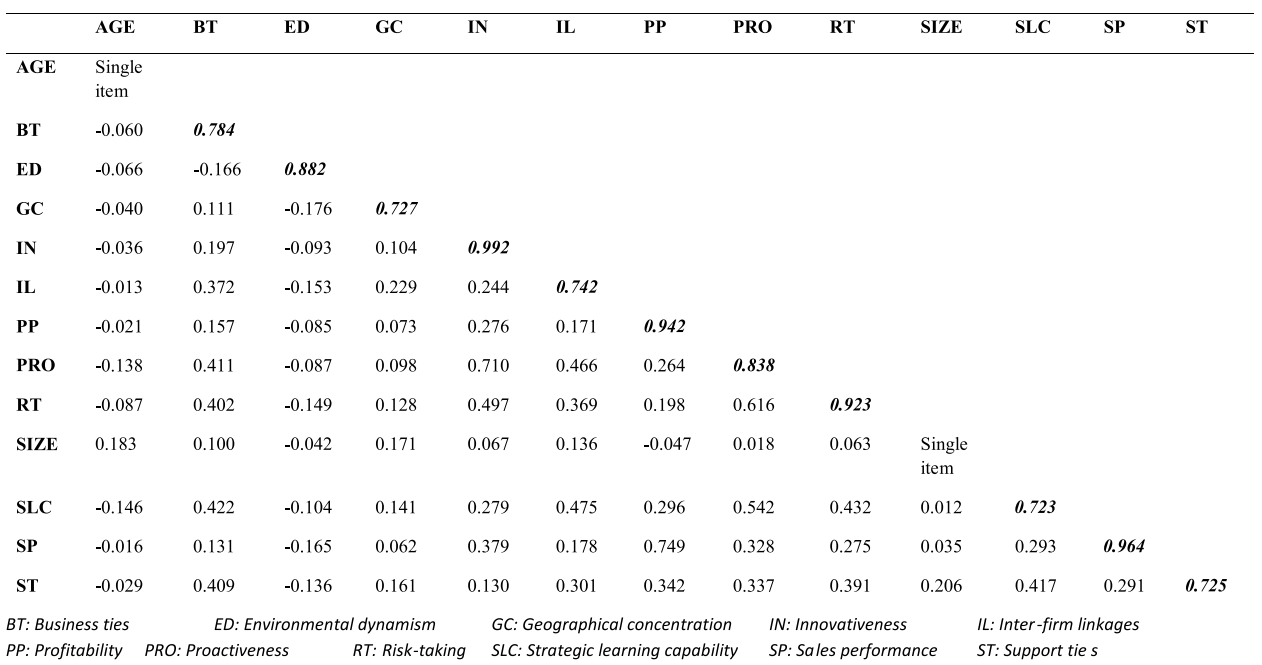

\section{Operationalization and Validation of Second-Order Constructs}

To assess the convergent validity of the second order cluster construct, an external global item was correlated with factor scores of its two dimensions. The overall item that covers the content of the formative construct is taken from Saric (2012:185) and is as follows: "overall our region provides us with all the resources (e.g. capital, suppliers, human resources, etc.) and access to markets we need for operating our business". The respective Spearman correlation coefficients are 0.382 and 0.212 and both are significant on the $1 \%$ level; therefore, convergent validity is established. 
Table 6

\section{Convergent Validity Values for Cluster}

\begin{tabular}{l|l|l} 
& & CL_Global \\
\hline Geographical concentration & Correlation Coefficient & $.382^{* *}$ \\
& Sig. (2-tailed) & .000 \\
\hline \multirow{2}{*}{ Inter-firm linkages } & Correlation Coefficient & $.212^{* *}$ \\
& Sig. (2-tailed) & .007 \\
\hline
\end{tabular}

**. Correlation is significant at the 0.01 level (2-tailed).

The entrepreneurial orientation construct is composed of three dimensions: proactiveness, innovativeness, and risk-taking. To assess content validity, all first-order factor scores were correlated with the global item "in this firm entrepreneurial behavior is a central principle" (Saric, 2012:184). The spearman correlation coefficients change between 0.557 and 0.717 and are significant at the $1 \%$ level. Hence, the entrepreneurial orientation construct has convergent validity.

Table 7

\section{Convergent Validity Values for Entrepreneurial Orientation}

\begin{tabular}{l|l|l} 
& & EO_Global \\
\hline Proactiveness & Correlation Coefficient & $.717^{* *}$ \\
& Sig. (2-tailed) & .000 \\
\hline Innovativeness & Correlation Coefficient & $.557^{* *}$ \\
& Sig. (2-tailed) & .000 \\
\hline Risk-taking & Correlation Coefficient & $.678^{* *}$ \\
& Sig. (2-tailed) & .000 \\
\hline
\end{tabular}

** Correlation is significant at the 0.01 level (2-tailed).

In the next step, the formative constructs are checked for collinearity, there are no values above the threshold value of 5 (Innovativeness, 2.043; Proactiveness, 2.475; Risk-taking, 1.629; Geographical concentration, 1.055, Inter-firm linkages, 1.055). Thus, there is no multicollinearity problem. The significance of the outer weights is presented in Table 8. 
Table 8

Outer Weights Significance Testing Results

\begin{tabular}{l|l|l|l|l} 
Construct & $\begin{array}{l}\text { Factor } \\
\text { Loadings }\end{array}$ & $\begin{array}{l}t \\
\text { value }\end{array}$ & $p$ value & $\begin{array}{l}\text { Significance } \\
\text { Level }\end{array}$ \\
\hline Geographical concentration $\rightarrow$ Cluster & 0.541 & 4.202 & .000 & $* * *$ \\
\hline Inter-firm linkages $\rightarrow$ Cluster & 0.726 & 6.793 & .000 & $* * *$ \\
\hline Proactiveness $\rightarrow$ Entrepreneurial orientation & 0.530 & 19.668 & .000 & $* * *$ \\
\hline Innovativeness $\rightarrow$ Entrepreneurial orientation & 0.352 & 16.193 & .000 & $* * *$ \\
\hline Risk-taking $\rightarrow$ Entrepreneurial orientation & 0.261 & 12.467 & .000 & $* * *$ \\
\hline
\end{tabular}

$* p<.10, * * p<.05, * * * p<.01$.

Both dimensions of the cluster construct, namely, geographical concentration and inter-firm linkages, load positive and significant $(\mathrm{p}<.01)$ on the cluster construct. As for the entrepreneurial orientation construct, proactiveness, innovativeness and risktaking load positive and significant $(\mathrm{p}<.01)$ on the entrepreneurial orientation construct.

Multicollinearity is checked before the evaluation of the path coefficients; all VIF values are below the threshold value VIF < 5 (Age, 1.084; Business ties, 1.415; Cluster, 1.653; Environmental dynamism, 1.077; Entrepreneurial orientation, 1.431; Size, 1.128; Strategic learning capability; 1.733; Support ties, 1.427).

\section{Analysis of the Structural Model and the Hypothesis Testing}

The analysis is composed of three parts. In the first part, the model with the control variables is assessed and the moderator variable cluster is not entered into the model; hypotheses $1,2,5$, and 7 are checked in this part. The second part involves the main effects including the moderator variable cluster. Finally, the third part comprises all variables and interactions; hypotheses $3,4,6$, and 8 are assessed in this part.

The results for the estimates with respect to profitability are shown in Table 9, and those for sales performance in Table 10. The tables show the path coefficients with their respective t-values, the coefficient of determination $\mathrm{R} 2$, and the Stone-Geisser criterion Q2 for predictive relevance. The effect size f 2 values, which are used to explore whether the changes in the coefficients of determination have substantive impact, are given for only statistically significant variables, namely support ties and entrepreneurial orientation.

Model 1 indicates a positive and significant effect of support ties on profitability $(\beta=0.287 ; p<.01)$ and sales performance $(\beta=0.210 ; p<.01)$. Also, entrepreneurial orientation has a positive and significant effect on profitability $(\beta=0.197 ; p<.05)$ and sales performance $(\beta=0.320 ; p<.01)$. The control variables age, size and environmental dynamism do not have a significant effect on profitability and sales performance. The R2 values of 0.182 and 0.225 show that both models have moderate explanatory power, while the Q2 values indicate acceptable predictive relevance. The f 2 effect sizes of support ties ( 0.069 for profitability; 0.041 for sales performance) and entrepreneurial orientation ( 0.024 for profitability; 0.107 for sales performance) are both considered 
small for profitability and sales performance.

Model 2 indicates a positive and significant effect of support ties on profitability $(\beta=0.287 ; p<.01)$ and sales performance $(\beta=0.211 ; p<.01)$. Again, entrepreneurial orientation has a positive and significant effect on profitability $(\beta=0.200 ; p<.05)$ and sales performance $(\beta=0.325 ; \mathrm{p}<.01)$. The control variables age, size and environmental dynamism do not have a significant effect on profitability and sales performance. The $\mathrm{R} 2$ values of 0.192 and 0.225 show that both models have moderate explanatory power, while the Q2 values indicate acceptable predictive relevance. The $\mathrm{f} 2$ effect sizes of support ties ( 0.074 for profitability; 0.041 for sales performance) and entrepreneurial orientation ( 0.037 for profitability; 0.108 for sales performance) are both considered small for profitability and sales performance.

Model 3 indicates a positive and significant effect of support ties on profitability $(\beta=0.274 ; p<.01)$ and sales performance $(\beta=0.205 ; p<.05)$. As for entrepreneurial orientation, it has a positive and significant effect on profitability $(\beta=0.186 ; p<.10)$ and sales performance $(\beta=0.312 ; p<.01)$. The control variables age, size and environmental dynamism do not have a significant effect on profitability and sales performance. The $\mathrm{R} 2$ values of 0.229 and 0.257 show that both models have moderate explanatory power, while the Q2 values indicate acceptable predictive relevance. The $\mathrm{f} 2$ effect sizes of support ties ( 0.068 for profitability; 0.039 for sales performance) and entrepreneurial orientation ( 0.032 for profitability; 0.100 for sales performance) are both considered small for profitability and sales performance. Concerning the significance of the twoway interaction effects, none of them are found significant for both profitability and sales performance thus, giving no support for hypotheses $3,4,6$, and 8 . The results indicate that only entrepreneurial orientation and support ties have a significant and positive effect on both profitability and sales performance, the variable cluster does not moderate any of the relationships presented in the theoretical model. 
Table 9

PLS Path Analysis Results for Profitability

\begin{tabular}{|c|c|c|c|c|}
\hline & Profitability & Model 1 & Model 2 & Model3 \\
\hline \multicolumn{5}{|l|}{ No moderator model } \\
\hline & Business ties & -0.071 & & \\
\hline & Support ties & $0.287 * * *$ & & \\
\hline & Entrepreneurial orientation & $0.197 * *$ & & \\
\hline & Strategic learning capability & 0.117 & & \\
\hline & Environmental dynamism & -0.063 & & \\
\hline & Age & 0.037 & & \\
\hline & Size & -0.123 & & \\
\hline \multicolumn{5}{|l|}{ Main effects model } \\
\hline & Business ties & & -0.069 & -0.053 \\
\hline & Support ties & & $0.287 * * *$ & $0.274 * * *$ \\
\hline & Entrepreneurial orientation & & $0.200^{* *}$ & $0.186^{*}$ \\
\hline & Strategic learning capability & & 0.122 & 0.083 \\
\hline & Environmental dynamism & & -0.065 & -0.065 \\
\hline & Age & & 0.038 & 0.052 \\
\hline & Size & & -0.121 & -0.129 \\
\hline & Cluster & & -0.016 & 0.059 \\
\hline \multicolumn{5}{|l|}{ Interactions } \\
\hline & Business ties $\mathrm{x}$ Cluster & & & -0.129 \\
\hline & Support ties x Cluster & & & 0.062 \\
\hline & Entrepreneurial orientation x Cluster & & & -0.089 \\
\hline & Strategic learning capability x Cluster & & & -0.067 \\
\hline & $\mathrm{R}^{2}$ & 0.182 & 0.192 & 0.229 \\
\hline & $\mathrm{Q}^{2}$ & 0.074 & 0.062 & 0.036 \\
\hline
\end{tabular}

${ }^{*} p<.10,{ }^{* *} p<.05, * * * p<.01$ 
Table 10

PLS Path Analysis Results for Sales Performance

\begin{tabular}{|c|c|c|c|c|}
\hline & Sales Performance & Model 1 & Model 2 & Model3 \\
\hline \multicolumn{5}{|l|}{ No moderator model } \\
\hline & Business ties & -0.117 & & \\
\hline & Support ties & $0.210 * * *$ & & \\
\hline & Entrepreneurial orientation & $0.320 * * *$ & & \\
\hline & Strategic learning capability & 0.119 & & \\
\hline & Environmental dynamism & -0.109 & & \\
\hline & Age & 0.021 & & \\
\hline & Size & -0.025 & & \\
\hline \multicolumn{5}{|l|}{ Main effects model } \\
\hline & Business ties & & -0.112 & -0.098 \\
\hline & Support ties & & $0.211 * * *$ & $0.205^{* *}$ \\
\hline & Entrepreneurial orientation & & $0.325 * * *$ & $0.312^{* * *}$ \\
\hline & Strategic learning capability & & 0.129 & 0.083 \\
\hline & Environmental dynamism & & -0.112 & -0.121 \\
\hline & Age & & 0.021 & 0.038 \\
\hline & Size & & -0.022 & -0.020 \\
\hline & Cluster & & -0.031 & 0.011 \\
\hline \multicolumn{5}{|l|}{ Interactions } \\
\hline & Business ties $x$ Cluster & & & -0.015 \\
\hline & Support ties x Cluster & & & 0.032 \\
\hline & Entrepreneurial orientation x Cluster & & & -0.063 \\
\hline & Strategic learning capability x Cluster & & & -0.155 \\
\hline & $\mathrm{R} 2$ & 0.225 & 0.225 & 0.257 \\
\hline & Q2 & 0.108 & 0.101 & 0.077 \\
\hline
\end{tabular}

${ }^{*} p<.10,{ }^{* *} p<.05, * * * p<.01$

\section{Discussion}

The findings indicate that support ties have a significant positive effect on both sales performance and profitability. This finding is in line with the literature on social ties; social networking and ties are ubiquitous in the emerging economies of Africa, the Middle East, and Asia because of their strong collectivistic cultures. Also, Peng and Luo's (2000) research in China shows that ties with officials are more important than ties with managers at other firms. 
As mentioned earlier in this paper, the state affected the industrialization of the Turkish business environment. Though the relationships with people from the government and state banks play a less important role in the support ties and firm performance relationship, managerial ties with people from municipalities and tax bureaus seem to be more effective. Hence, the impact of governmental institutions on firm performance, and especially on profitability, should not be neglected. The role of the personal relationships with officials from chambers of commerce and industry is also important. Apart from the services offered by these chambers, firms may also see them as a medium through which to communicate their problems and demands to the government. The relationships with people from educational institutions and with political people from the government seem to be less effective on performance compared to the institutions mentioned above.

As for entrepreneurial orientation, the results seem to be congruent with the literature. It has a more salient impact on sales performance than profitability, as its impact can be seen more quickly on sales than profit figures. Firms with an entrepreneurial orientation engage often in risk-taking behavior, that is, they incur heavy debt or make large resource commitments, in the hope of obtaining high returns by seizing opportunities in the marketplace (Lumpkin and Dess, 1996). Therefore, the return on investments and profit figures may be insufficient in the short term but they may ameliorate in the long term.

The positively hypothesized relationship between strategic learning and performance was not supported. However, strategic learning capacity can be useful for firms with entrepreneurial orientation in the long run; firms acting fiercely on an entrepreneurial orientation take an unnecessary risk. These firms can easily get involved in a series of activities, such as experimentation, search, and innovation, that consume a hefty part of their resources without developing the ability to incorporate the rents they create. Strategic learning capability might help them in the exploitation of the newly-explored opportunities and consequently, it might yield positive incomes.

The positively hypothesized impact of business ties on firm performance was also not significant. This finding contradicts Zhang and Li's findings (2008) indicating that business ties have greater positive effects on sales growth than support ties, but it is in accordance with Peng and Luo's (2000) findings. The business ties that the managers have with suppliers, buyers and competitors do not seem to produce sales or improve profitability. They might need to improve the quality of their ties and maybe turn them into networks of information and collaborate to ameliorate the performance and the competitiveness of their cluster in total. When managers, their key customers and suppliers interact in networking relationships they may, consequently, create, acquire and exploit knowledge. In addition, networking relationships with customers may produce loyal customers, and increase sales, while those with suppliers will give the opportunity to benefit from quality raw materials, superior service, and fast and reliable deliveries. Moreover, when managers create ties with their competitors, they may learn how to reduce operations cost, collaborate to share resources, or implicitly deal together with competitive uncertainties in their environment (Acquaah, 2007). 
As for the cluster variable, the results indicate that this does not significantly moderate the relationships presented in the model. It also does not have a significant main effect on firm performance. This finding is in line with the finding of the research carried out by Liao (2010); clusters alone have no impact on performance. However, Liao (2010) found that manufacturing resources facilitate a positive relationship between clusters and manufacturing performance.

Finally, the results of this study can be explained by the premises of the institutional theory. Firms are subject to coercive isomorphism in Turkey as the government and other governmental institutions can influence their performance by promulgating regulations and restrictions. Therefore, firms that conform to these rules and grow good relationships with these institutions are considered legitimate. Organizations that appear to be legitimate are more likely to access resources than organizations that do not appear to be legitimate. They may obtain subventions, government contracts, tax exemptions etc., which, in turn, will ameliorate their position in the competition.

Furthermore, clusters are propitious environments for normative isomorphism to thrive. Normative isomorphism refers to following standards and practices established by education and training methods, professional networks, and movements of employees among firms. Firms may be legitimate by applying these standards and practices without questioning them, but they cannot be efficient and competitive as they all apply the same business practices. Those with an entrepreneurial orientation differ from those who take institutionalized actions. Hence, they may find new ways to increase their efficiency and productivity by being proactive, innovative and risk-taking. They will most likely detect and seize the opportunities before the institutionalized firms do in their cluster. Therefore, entrepreneurial orientation has a significant and positive impact on firm performance, as indicated by the results of this study.

\section{Conclusions, Limitations and Implications}

Clusters have been studied for almost a century by academia, but it was Michael Porter who elevated the cluster to stardom with his diamond framework. The present study tried to find answers to the following research question: How do firms create and defend competitive advantages through clusters?

This study tried to build and test a model to explore the firm characteristics that lead to performance differences among firms. Using a PLS path model, the findings confirmed only that entrepreneurial orientation and support ties contributed significantly and positively to firm performance. Business ties did not have a significant impact on performance.

Unlike other studies, this study incorporated two clusters from the service sector, the Antalya and Muğla tourism clusters. Generally, studies in the literature focus on manufacturing industries and neglect the service sector.

As for the managerial implications of this study, managers should focus on their entrepreneurial orientation and support ties in order to improve their sales performance and profitability in the Turkish context. 
This study is not without its limitations. The survey was conceived as a cross-industry study. Therefore, the results of the study have external validity, but industry-specific studies could reveal additional insights. There is a need to assess to what extent the results of this study hold true if it is replicated in knowledge-based industries or other service industries such as finance, media and so on. Also, the clusters chosen in this study should also be the subject of further studies, as it was not possible to conduct a multigroup analysis to see the differences among the clusters, owing to sample requirements. Qualitative studies can be carried out in conjunction with quantitative studies to figure out the reasons for the insignificant results.

Another limitation is about the data that was gathered during the empirical survey. As mentioned earlier, the same informants provided information on both the dependent and independent variables. Whereas all necessary precautions were taken to avoid common method bias, replicating the survey with actual financial performance figures could lead to interesting findings. Also, as mentioned above, due to the method chosen to collect data, there is a self-selection bias for small and medium-sized firms. Unfortunately, micro-firms are not well represented in the sample of this study although they make up more than half of the population in the clusters selected. The results of this study might have been different if more micro-firms had participated in the survey.

There was no significant moderator effect of the variable cluster with the variables entered in the model. The findings might seem at odds with the arguments of the cluster literature, but the sample consists of firms from nine different clusters in six different industries in Turkey, including two clusters from the service sector. Therefore, they have different characteristics with regard to geographical concentration, development of informal and formal links. Moreover, they can be in different stages of their lifecycle, such as the Ankara furniture cluster, which is in the late stages of its lifecycle. Thus, the results may yield significant results for certain clusters and not for others. The results can be considered as a snapshot of Turkish clusters. Unfortunately, a multigroup analysis could not be made in this study because of the sample requirements for such an analysis.

Also, this study uses subjective measures of firm performance based on the judgment of the respondents, as Turkish managers do not generally want to provide financial performance data. This use of subjective measures is often preferred in the Turkish context (Tatoglu and Glaister, 1998; Kula, 2005). However, if the objective performance measures and the subjective ones are not congruent, the results might indicate different significant relationships, or the importance of some relationships might decrease or increase. But if the performance measures are in harmony, the findings of this study show that clusters do not have a significant impact on the performance of Turkish firms as they are. Thus, there is room for development; cluster members, including educational and financial institutions, government and chambers of commerce and industry should brainstorm and propose suggestions to improve the conditions of the clusters in order to reap benefits from them.

Finally, this research study is among the few studies that try to bring the cluster research back to the firm; it has identified that support ties and entrepreneurial orientation help firms to create and defend competitive advantage through clusters. The fact that 
the model explains $23 \%$ and $25 \%$ of variance of profitability and sales performance, respectively, suggests that there are more firm-level characteristics that could interact with clusters and firm performance.

\section{References}

Acquaah, M. (2007). "Managerial Social Capital, Strategic Orientation, and Organizational Performance in an Emerging Economy," Strategic Management Journal, 28: 1235-1255.

Asheim, B., Cooke, P., and Martin, R. (2006). Clusters and Regional Development: Critical Reflections and Explorations. Oxon: Routledge.

Becattini, G. (1990). "The Marshallian Industrial District as a Socio-Economic Notion," in F. Pyke, G. Becattini, W. Sengenberger (ed.), Industrial Districts and Inter-Firm Co-Operation in Italy: 37-51. Geneva: International Institute for Labor Studies.

Berkman, Ü. and Özen, Ş. (2008). "Culture and Management in Turkey: State-Dependency and Paternalism in Transition," in E. Davel, J.P. Dupuis and J.F. Chanlat (ed.), Gestion en Contexte Interculturel : Approches, Problématiques, Pratiques et Plongées. Chapter VI.4. Québec : Presse de L’Université Laval et Téléuniversité (UQAM).

Buğra, A. (1994). State and Business in Modern Turkey: A Comparative Study. Albany: SUNY Press.

Covin, J.G., Green, K.M., and Slevin, D.P. (2006). "Strategic Process Effects on the Entrepreneurial Orientation-Sales Growth Rate Relationship," Entrepreneurship Theory and Practice, 30: 57-82.

Dimitratos, P., Lioukas, S., and Carter, S. (2004). "The Relationship Between Entrepreneurship and International Performance: The Importance of Domestic Environment," International Business Review, 13: 19-41.

Garrett, R.P., Covin, J.G., and Slevin, D.P. (2009). "Market Responsiveness, Top Management Risk Taking, and the Role of Strategic Learning as Determinants of Market Pioneering," Journal of Business Research, 62(8): 782-788.

Gilbert, B.A., McDougall, P.P., and Audretsch, D.B. (2008). "Clusters, Knowledge Spillovers, and New Venture Performance: An Empirical Examination," Journal of Business Venturing, 23(4): 405-422.

Krugman, P.R. (1991). "Increasing Returns and Economic Geography," Journal of Political Economy, 49: $137-150$.

Krugman, P.R. (1998). "What's New in the Economic Geography," Oxford Review of Economic Policy, 14(2): 7-17.

Kukalis, S. (2010). "Agglomeration Economies and Firm Performance," Journal of Management, 36 (2): 453-481.

Lazzeretti, L. (2003). "City of Art as High Culture Local System and Cultural Districtualisation Process: The Cluster of Art Restoration in Florence," International Journal of Urban and Regional Research, 27: 635-648.

Li, J. and Geng, S. (2012). "Industrial Clusters, Shared Resources and Firm Performance," Entrepreneurship \& Regional Development: An International Journal, 24(5-6): 357-381.

Liao, T. (2010). "Cluster and Performance in Foreign Firms: The Role of Resources Knowledge, and Trust," Industrial Marketing Management, 39: 161-169.

Lumpkin, G.T. and Dess, G.G. (1996). "Clarifying the Entrepreneurial Orientation Construct and 
Linking It to Firm Performance," Academy of Management Review, 21: 135-172.

Marshall, A. (1927). Industry and Trade: A Study of Industrial Technique and Business Organization, and of Their Influences on the Conditions of Various Classes and Nations. London: MacMillan.

McCann, B.T. and Folta, T.B. (2011). "Performance Differentials within Geographic Clusters," Journal of Business Venturing, 26: 104-123.

Oba, B. and Semerciöz, F. (2005). "Antecedents of Trust in Industrial District: An Empirical Analysis of Inter-Firm Relations in a Turkish Industrial District," Entrepreneurship \& Regional Development: An International Journal, 17(3): 163-182.

Oz, O. (2004). Clusters and Competitive Advantage: The Turkish Experience. Hampshire, UK: Palgrave MacMillan.

Peng, M.W. and Luo, Y. (2000). "Managerial Ties and Firm Performance in a Transition Economy:The Nature of a Micro-Macro Link," Academy of Management Journal, 43(3): 486-501.

Piore, M. and Sabel, C. (1984). The Second Industrial Divide. New York (NY): Basic Books.

Porter, M.E. (1990). The Competitive Advantage of Nations. New York (NY): The Free Press.

Porter, M.E. (2008). On Competition. Updated and Expanded Edition. Boston (MA): Harvard Business School Press.

Rauch, A., Wiklund, J., Lumpkin, G.T., and Frese, M. (2009). "Entrepreneurial Orientation and Business Performance: An Assessment of Past Research and Suggestions for the Future," Entrepreneurship Theory and Practice, 33(3): 761-787.

Rocha, H.O. and Sternberg, R. (2005). "Entrepreneurship: The Role of Clusters, Theoretical Perspectives and Empirical Evidence from Germany," Small Business Economics, 24: 267-292.

Sabel, C.F., Piore, M.J., and Storper, M. (1990). "Three Responses to Ash Amin and Kevin Robbins," in F. Pyke, G. Becattini, and W. Sengenberger (ed.), Industrial Districts and Inter-Firm Cooperation in Italy: 220-237.Geneva: International Institute for Labor Studies

Saric, S. (2012). Competitive Advantages through Clusters: An Empirical Study with Evidence from China. Wiesbaden: Springer Gabler.

Scott, A. (1988). New Industrial Spaces, London: Pion.

Siren, C.A., Kohtamaki, M., and Kuckertz, A. (2012). "Exploration and Exploitation Strategies, Profit Performance, and the Mediating Role of Strategic Learning: Escaping the Exploitation Trap," Strategic Entrepreneurship Journal, 6: 18-41.

Storper, M. (1997). The Regional World: Territorial Development in a Global Economy. New York (NY): Guilford Press.

Varaldo, R. and Ferruci, L. (1996). "The Evolutionary Nature of the Firm within Industrial Districts," European Planning Studies, 4: 27-34.

Wennberg, K. and Lindqvist,, G. (2010). "The Effect of Clusters on the Survival and Performance of New Firms," Small Business Economics, 34(3): 221-241.

Wiklund, J. and Shepherd, D. (2005). "Entrepreneurial Orientation and Small Business Performance," Journal of Business Venturing, 20: 71-91.

Zahra, S.A. and Covin, J.G. (1995). "Contextual Influences on the Corporate Entrepreneurship Performance Relationship: A Longitudinal Analysis," Journal of Business Venturing, 10: 43-58. 
Zahra, S.A. and Garvis, D.M. (2000). "International Corporate Entrepreneurship and Firm Performance: The Moderating Effect of International Environmental Hostility," Journal of Business Venturing, 15(5-6): 469-492.

Zhang, S. and Li, X. (2008). "Managerial Ties, Firm Resources, and Performance of Cluster Firms," Asia Pacific Journal of Management, 25(4): 615-633. 


\section{APPENDIX}

\section{QUESTIONNAIRE}

\section{1-Please compare your industry to other industries in your region} (1=Very Low; 5=Very High).

\begin{tabular}{|c|c|c|c|c|c|}
\hline & 1 & 2 & 3 & 4 & 5 \\
\hline $\begin{array}{l}\text { The number of companies operating in our industry compared to th } \\
\text { number of companies operating in other industries. }\end{array}$ & & & & & \\
\hline $\begin{array}{l}\text { The number of people employed in our industry compared to the } \\
\text { number of people employed by other industries }\end{array}$ & & & & & \\
\hline $\begin{array}{l}\text { The percentage our industry contributes to the regional gross value } \\
\text { added compared to the total regional gross value added. }\end{array}$ & & & & & \\
\hline
\end{tabular}

2-To what extent do you agree or disagree with the following statements? ( $1=$ Strongly Disagree; $5=$ Strongly Agree $)$

\begin{tabular}{|c|c|c|c|c|c|}
\hline & 1 & 2 & 3 & 4 & 5 \\
\hline \multicolumn{6}{|l|}{$\begin{array}{l}\text { Our region is home to a large number of suppliers and potential } \\
\text { customers. }\end{array}$} \\
\hline \multicolumn{6}{|l|}{$\begin{array}{l}\text { We have built networks and alliances with our local business } \\
\text { partners. }\end{array}$} \\
\hline \multicolumn{6}{|l|}{$\begin{array}{l}\text { Our employees regularly participate in relevant local industry } \\
\text { events. }\end{array}$} \\
\hline \multicolumn{6}{|l|}{$\begin{array}{l}\text { In our local business environment, it is common that employees who } \\
\text { switch jobs move from one local company to another. }\end{array}$} \\
\hline \multicolumn{6}{|l|}{$\begin{array}{l}\text { Overall our region provides us with all the resources (e.g. capital, } \\
\text { suppliers, human resources, etc.) and access to markets we need for } \\
\text { operating our business. }\end{array}$} \\
\hline \multicolumn{6}{|l|}{$\begin{array}{l}\text { Overall, my firm regularly scans the environment and gathers } \\
\text { information from our local business partners to seek and identify } \\
\text { new opportunities. }\end{array}$} \\
\hline \multicolumn{6}{|l|}{$\begin{array}{l}\text { In general, the top managers of my firm initiate pre-emptive actions } \\
\text { in response to perceived opportunities which competitors then } \\
\text { respond to. }\end{array}$} \\
\hline \multicolumn{6}{|l|}{$\begin{array}{l}\text { We are very often the first to introduce new products or services to } \\
\text { our customers. }\end{array}$} \\
\hline \multicolumn{6}{|l|}{ In general, my firm is eager to be a leader rather than a follower. } \\
\hline \multicolumn{6}{|l|}{$\begin{array}{l}\text { During the past three years my firm has marketed very many new } \\
\text { lines of products and services. }\end{array}$} \\
\hline \multicolumn{6}{|l|}{ Changes in product and service lines have been quite dramatic. } \\
\hline \multicolumn{6}{|l|}{$\begin{array}{l}\text { In my firm, managers have a strong proclivity for high-risk projects } \\
\text { (with chances of very high returns). }\end{array}$} \\
\hline \multicolumn{6}{|l|}{$\begin{array}{l}\text { In my firm, managers believe that owing to the nature of the } \\
\text { environment, bold wide-ranging acts are necessary to achieve the } \\
\text { firm's objectives. }\end{array}$} \\
\hline In this firm entrepreneurial behavior is a central principle. & & & & & \\
\hline
\end{tabular}


3-To what extent have you utilized personal ties, networks, and connections with the top executives...

\section{$(1=$ Very Little; $5=$ Very Extensive $)$}

\begin{tabular}{l|l|l|l|l|l} 
& 1 & 2 & 3 & 4 & 5 \\
\hline$\ldots$ at supplier firms during the past three years? & & & & & \\
\hline$\ldots$ at buyer firms during the past three years? & & & & & \\
\hline$\ldots$ at competitor firms during the past three years? & & & & & \\
\hline
\end{tabular}

4- To what extent have you utilized personal ties, networks, and connections with... (1=Very Little; $5=$ Very Extensive $)$

\begin{tabular}{|c|c|c|c|c|c|}
\hline & 1 & 2 & 3 & 4 & 5 \\
\hline $\begin{array}{l}\text {...political persons from the government during the pas } \\
\text { years? }\end{array}$ & & & & & \\
\hline ...people from educational institutions during the past & & & & & \\
\hline ...officials in municipalities during the past three years & & & & & \\
\hline ...officials in state banks during the past three years? & & & & & \\
\hline ...officials in tax bureaus during the past three years? & & & & & \\
\hline ...officials in chambers of commerce during the past th & & & & & \\
\hline ...officials in chambers of industry during the past thre & & & & & \\
\hline ...officials in cooperatives during the past three years? & & & & & \\
\hline
\end{tabular}

5- To what extent do you agree or disagree with the following statements? ( $1=$ Strongly Disagree; $5=$ Strongly Agree $)$

\begin{tabular}{|c|c|c|c|c|c|}
\hline & 1 & 2 & 3 & 4 & 5 \\
\hline \multicolumn{6}{|l|}{ Within our firm, sharing strategic information is the norm. } \\
\hline \multicolumn{6}{|l|}{$\begin{array}{l}\text { Within our firm, strategically important information is easily } \\
\text { accessible to those who need it most. }\end{array}$} \\
\hline \multicolumn{6}{|l|}{$\begin{array}{l}\text { Representatives from different departments meet regularly to } \\
\text { discuss new strategically important issues. }\end{array}$} \\
\hline \multicolumn{6}{|l|}{$\begin{array}{l}\text { Within our firm, strategically important information is actively } \\
\text { shared between different departments. }\end{array}$} \\
\hline \multicolumn{6}{|l|}{$\begin{array}{l}\text { When one department obtains strategically important information, } \\
\text { it is circulated to other departments. }\end{array}$} \\
\hline \multicolumn{6}{|l|}{$\begin{array}{l}\text { When faced with new strategically important information, our } \\
\text { managers usually agree on how the information will impact our } \\
\text { firm. }\end{array}$} \\
\hline \multicolumn{6}{|l|}{$\begin{array}{l}\text { In meetings, we seek to understand everyone's point of view } \\
\text { concerning new strategic information. }\end{array}$} \\
\hline \multicolumn{6}{|l|}{$\begin{array}{l}\text { Groups are prepared to rethink decisions when presented with new } \\
\text { strategic information. }\end{array}$} \\
\hline $\begin{array}{l}\text { When confronting new strategic information, we are not afraid } \\
\text { to critically reflect on the shared assumptions we have about our } \\
\text { organization. }\end{array}$ & & & & & \\
\hline
\end{tabular}




\begin{tabular}{|c|}
\hline $\begin{array}{l}\text { We often collectively question our own biases about the way } \\
\text { interpret new strategic knowledge. }\end{array}$ \\
\hline $\begin{array}{l}\text { Strategic knowledge gained by working groups is used to imp } \\
\text { products, services, and processes. }\end{array}$ \\
\hline $\begin{array}{l}\text { The decisions we make according to any new strategic knowl } \\
\text { are reflected in changes to our organizational systems and } \\
\text { procedures. }\end{array}$ \\
\hline $\begin{array}{l}\text { Strategic knowledge gained by individuals has an effect on th } \\
\text { organization's strategy }\end{array}$ \\
\hline $\begin{array}{l}\text { Recommendations by groups concerning the use of strategic } \\
\text { knowledge are adopted by the organization. }\end{array}$ \\
\hline
\end{tabular}

6- Please assess your firm's performance relative to your competitors over the three years 2012/2013/2014 in terms of...

(1=Very Unsatisfactory; 5= Very Satisfactory)

\begin{tabular}{|c|c|c|c|c|c|}
\hline & 1 & 2 & 3 & 4 & 5 \\
\hline ...return on investment. & & & & & \\
\hline ...profit margin & & & & & \\
\hline ...net profits & & & & & \\
\hline ...sales volume & & & & & \\
\hline ...growth in sales volume & & & & & \\
\hline
\end{tabular}

7- How would you assess your firm's business environment with the following statements? (1=Strongly Disagree; 5= Strongly Agree)

\begin{tabular}{|c|c|c|c|c|c|}
\hline & 1 & 2 & 3 & 4 & 5 \\
\hline Product demand is hard to forecast. & & & & & \\
\hline Customer requirements and preferences are hard to forecast. & & & & & \\
\hline $\begin{array}{l}\text { My industry is very unstable with huge change resulting from major } \\
\text { economic, technological, social, or political forces }\end{array}$ & & & & & \\
\hline
\end{tabular}

8- Other

\begin{tabular}{l|l}
\hline Number of employees & \\
\hline $\begin{array}{l}\text { Industry in which your } \\
\text { company operates }\end{array}$ & \\
\hline Company age & \\
\hline Company name & \\
\hline Company location & \\
\hline $\begin{array}{l}\text { Title of the person who } \\
\text { filled out this questionnaire }\end{array}$ & \\
\hline
\end{tabular}

